\title{
STUDIES ON MINERAL NUTRITION OF THE COFFEE PLANT (Coffea arabica L. cv. CATUAÍ VERMELHO). LXIV. REMOBILIZATION AND RE-UTILIZATION OF NITROGEN AND POTASSIUM BY NORMAL AND DEFICIENT PLANTS
}

\author{
LIMA FILHO, O. F. de $^{1}$ and MALAVOLTA, E. ${ }^{2}$ \\ ${ }^{1}$ Embrapa Agropecuária Oeste, C.P. 661, CEP 79804-970, Dourados, MS, Brazil \\ ${ }^{2}$ Centro de Energia Nuclear na Agricultura, CENA, Universidade de São Paulo, C.P. 96, \\ CEP 13400-970, Piracicaba, SP, Brazil \\ Correspondence to: Eurípedes Malavolta, Centro de Energia Nuclear na Agricultura, CENA, Universidade de São \\ Paulo, C.P. 96, CEP 13400-970, Piracicaba, SP, Brazil, e-mail: mala@cena.usp.br \\ Received April 22, 2002 - Accepted August 27, 2002 - Distributed August 31, 2003
}

(With 2 figures)

\begin{abstract}
Remobilization and re-utilization of ${ }^{15} \mathrm{~N}$ and ${ }^{85} \mathrm{Rb}$ labelled nitrogen and potassium reserves for new growth and fruit formation was studied under greenhouse conditions using both normal and deficient young coffee plants. It was found that $\mathrm{K}$ reserves are used in higher proportion than is stored $\mathrm{N}$ by fruits and other organs. The export of $\mathrm{N}$ by organs of residence in the normal plants obeyed the following proportions of the total: leaves $47 \%-58 \%$, branches and flower buds $21 \%-27 \%$, roots $21 \%-32 \%$. The corresponding figures in the case of deficient plants were: leaves $49 \%-65 \%$, branches and flower buds $21 \%-27 \%$, roots $14 \%-25 \%$. Re-utilization of $\mathrm{K}$ took place in the following proportions in the normal plants: leaves $54 \%-64 \%$, branches and flower buds $20 \%-21 \%$, roots $30 \%-41 \%$. In K deficient plants the figures were: leaves $62 \%-79 \%$, branches and flower buds $1.2 \%-4.4 \%$, roots $20 \%-33 \%$. In tissues formed after the initiation of flowering buds, the demand for $\mathrm{N}$ is met by reserves as follows: normal plants: fruits $20.6 \%-24.8 \%$, leaves $15.6 \%-19.4 \%$, twigs $19 \%-20.5 \%$; deficient plants: fruits 43.5\%-48.5\%, leaves $48.1 \%-51.9 \%$, twigs $46 \%-53 \%$. The K needs for new tissues are met in the order: normal plants: fruits $40 \%-45.8 \%$, leaves $27 \%-37.6 \%$, twigs $26 \%-33.1 \%$; deficient plants: fruits $65.7 \%$ $81.5 \%$, leaves $52.6 \%-68.4 \%$, twigs $62 \%-86.1 \%$. Fruits represent the main sink for both $\mathrm{N}$ and K. Reutilization of both elements is higher in the case of deficient plants.
\end{abstract}

Key words: re-utilization, remobilization, nitrogen, potassium, rubidium, coffee plants, ${ }^{15} \mathrm{~N},{ }^{85} \mathrm{Rb}$.

\section{RESUMO}

Estudos sobre a nutrição mineral do cafeeiro (Coffea arabica L. cv. Catuaí Vermelho). LXIV. Remobilização e reutilização de nitrogênio e potássio por plantas normais e deficientes

A remobilização do $\mathrm{N}\left({ }^{15} \mathrm{~N}\right)$ e do $\mathrm{K}\left({ }^{85} \mathrm{Rb}\right)$ de reserva e seu uso pelas diferentes partes do cafeeiro (Coffea arabica cv. Catuaí Vermelho) no período reprodutivo, particularmente pelos frutos, foram estudados sob condições normais e de carência de $\mathrm{N}$ ou $\mathrm{K}$. O K de reserva, comparado ao $\mathrm{N}$ de reserva, é utilizado em maior proporção pelos frutos e demais órgãos do cafeeiro. A exportação do $\mathrm{N}$ pelos órgãos de reserva foi a seguinte: plantas normais - folhas (47\%-58\%); ramos + gemas florais (20\%-21\%); raízes (21\%$32 \%)$. Plantas deficientes - folhas (49\%-65\%); ramos + gemas florais (21\%-27\%); raízes (14\%-25\%). A remobilização do K de reserva ocorreu na seguinte proporção: plantas normais - folhas (54\%-64\%); ramos + gemas florais (20\%-21\%); raízes (30\%-41\%). Plantas deficientes - folhas (62\%-79\%); ramos + gemas florais (1,2\%-4,4\%); raízes (20\%-33\%). Em tecidos lançados após a iniciação da gema floral, 
a demanda por $\mathrm{N}$ é coberta pelas reservas do cafeeiro com o seguinte porcentual: plantas normais - frutos (20,6\%-24,8\%), folhas (15,6\%-19,4\%), ramos (19,0\%-20,5\%); plantas deficientes: frutos (43,5\%-48,5\%); folhas $(48,1 \%-51,9 \%)$; ramos $(46,0 \%-53,0 \%)$. Para o K em plantas normais: frutos $(40,0 \%-45,8 \%)$, folhas $(27,0 \%-37,6 \%)$, ramos (26\%-33,1\%); plantas deficientes: frutos $(65,7 \%-81,5 \%)$; folhas $(52,6 \%-68,4 \%)$; ramos $(62,0 \%-86,1 \%)$.

Palavras-chave: reutilização, remobilização, nitrogênio, potássio, rubídio, cafeeiro, ${ }^{15} \mathrm{~N},{ }^{85} \mathrm{Rb}$.

\section{INTRODUCTION}

Coffee plants have high $\mathrm{N}$ and $\mathrm{K}$ requirements (Catani \& Moraes, 1958; Malavolta et al., 1963; Catani et al., 1967; Correa et al., 1983). There is a close relationship among nitrogen supply, number of leaves, and number of flower buds (Dierendonck, 1959). Whereas adequate tissue $\mathrm{N}$ levels are favorable for starch and other carbohydrate production needed for fruit formation and growth, in deficient plants symptoms develop particularly when the berries grow (Malavolta, 1986).

Potassium also plays a major role in coffee plant physiology especially during fruit growth and maturation. The K quantity exported at harvest exceeds that of $\mathrm{N}$ which helps to explain why it can become limiting after a few years (Mitchell, 1988). A good correlation exists between the $\mathrm{K}$ status, as measured by leaf content, and stored starch and yield. When tissue $\mathrm{K}$ is adequate the proportion of floats and branches with symptoms of overbearing decreases (Glander, 1958; Malavolta, 1986).

The remobilization and re-utilization of certain nutrients is an important metabolic feature during development or in cases of seed germination, under stress conditions in the period of vegetative growth and the reproductive stage as well and, in the case of perennials, before leaf fall. As indicated by deficiency symptoms which develop in the leaves, the degree of both $\mathrm{N}$ and $\mathrm{K}$ mobilization is large (Marschner, 1995).

There is a lack of studies dealing with $\mathrm{N}$ and $\mathrm{K}$ transport from organs of residence towards other ones, either vegetative or reproductive or both, under normal or deficiency conditions. The development of isotopic techniques has allowed better understanding of the mechanism involved in the uptake and transport of nutrients directly related to productivity increase and sustainability. In the present contribution the isotopic dilution technique was used with the stable isotopes ${ }^{15} \mathrm{~N}$ for nitrogen and ${ }^{85} \mathrm{Rb}$ for potassium. ${ }^{15} \mathrm{~N}$ is intensively used as a tracer in soil-plant system studies. It has also been shown that ${ }^{85} \mathrm{Rb}$, a stable isotope, can be used as a tracer for K (Calvache et al., 1990).

Hydrated potassium and rubidium have a similar ionic radius and both cations occupy the same binding sites on the plasma membrane of root cells (Erdei \& Trivedi, 1991). Although Rb cannot replace $\mathrm{K}$ in its metabolic roles, rubidium is capable of replacing potassium in proton transfer at the tonoplast level (Nakaoji et al., 1991; Marschner, 1995).

${ }^{86} \mathrm{Rb}$ has been used in biological research as a tracer for K (Pettersson \& Strid, 1989; Hughes et al., 1990; Kuhlmann, 1990; Peng et al., 1990; Gussarsson \& Jensen, 1992). The use of ${ }^{42} \mathrm{~K}$ in experiments of short and medium duration is practically impossible due its unsuitable half-life (12.4 hours as opposed to 18.7 days for ${ }^{86} \mathrm{Rb}$ ), and low specific activity (Vose, 1980). The stable isotope ${ }^{85} \mathrm{Rb}$, on the other hand, has proved to be a safe and adequate tracer, notwithstanding the experimental period length. Calvache et al. (1991), for instance, were able to quantify available $\mathrm{K}$ for a potato crop by using ${ }^{85} \mathrm{Rb}$, thereby showing the possibility of using this isotope to replace potassium. However, the literature makes no reference to studies on $\mathrm{K}$ re-utilization by plant tissue involving the use ${ }^{85} \mathrm{Rb}$.

The objectives of the present study were the following: to assess $\mathrm{N}$ and $\mathrm{K}$ export from the organs of residence as sources, to leaves, stem, and root, before flower differentiation; re-utilization of both elements by different coffee plant organs, between flowering and fruit maturation, by normal and $\mathrm{N}$ and $\mathrm{K}$ deficient young plants.

\section{MATERIAL AND METHODS}

The experiment was conducted in a greenhouse, beginning in November 1995. Thirty-six 14-monthold coffee plants (Coffea arabica cv. Catuaí Vermelho, 
IAC H2077-2-5-81) were transferred into $5 \mathrm{~L}$ earthenware pots containing continuously aerated nutrient solution. The containers were treated inside with waterproof paint and covered with black plastic to prevent alga growth and water loss by evaporation. Nutrient solution initial concentrations were the following in millimols: $\mathrm{KNO}_{3}-5.0 ; \mathrm{Ca}\left(\mathrm{NO}_{3}\right)_{2} \cdot 4 \mathrm{H}_{2} \mathrm{O}-$ 3.0; $\mathrm{NH}_{4} \mathrm{H}_{2} \mathrm{PO}_{4}-1.0 ; \mathrm{MgSO}_{4} \cdot 7 \mathrm{H}_{2} \mathrm{O}-1.0 ; \mathrm{NH}_{4} \mathrm{NO}_{3}-2.0$. Micronutrients were supplied as: $\mathrm{KCl}-50 ; \mathrm{H}_{3} \mathrm{BO}_{3}$ $25 ; \mathrm{MnSO}_{4} \cdot \mathrm{H}_{2} \mathrm{O}-2.0 ; \mathrm{ZnSO}_{4} .7 \mathrm{H}_{2} \mathrm{O}-2.0 ; \mathrm{CuSO}_{4} .5 \mathrm{H}_{2} \mathrm{O}-$ $0.5 ; \mathrm{H}_{2} \mathrm{MoO}_{4}\left(85 \% \mathrm{MoO}_{3}\right)-0.5 ; \mathrm{Fe}$ - ethilenediamine tetraacetic acid EDTA-20 $\mu \mathrm{M}$. Concentrations are given in micromols.

Plants were labelled with either ${ }^{15} \mathrm{~N}$ or ${ }^{85} \mathrm{Rb}$ in June-July 1996. Two applications of $0.96 \mathrm{~g}{ }^{85} \mathrm{RbCl}$ and of $1.32 \mathrm{~g}\left({ }^{15} \mathrm{NH}_{4}\right)_{2} \mathrm{SO}_{4}$ with $8 \%{ }^{15} \mathrm{~N}$ in excess were made. At the same time unlabelled plants were grown for determining natural $\mathrm{Rb}$ abundance in the various organs (Calvache et al., 1991).

Before flowering, at the onset of reproductive dormant buds, 4 plants were harvested (first harvest). Leaves, branches (orthotropic and plagiotropic), flower buds, and roots were analyzed, and ${ }^{15} \mathrm{~N}$, total $\mathrm{N},{ }^{85} \mathrm{Rb}$, and $\mathrm{K}$ determined. The labelled nutrient solutions were replaced by unlabelled ones in the remaining pots, and the roots were washed with distilled water. Twelve plants, corresponding to treatment 1 , were grown in full strength nutrient solution, including the usual $\mathrm{N}$ and $\mathrm{K}$ rates. The next twelve plants, i.e., treatment 2 , were given nutrient solution with one fourth of the $\mathrm{N}$ concentration. The remaining twelve plants, treatment 3 , received nutrient solution with one fourth of the usual $\mathrm{K}$ level. The final harvest took place in July 1997 when the majority of fruits were ripe, and the plants were 2 years 9 month old. Leaves and older branches originating in the flush previous to the first harvest were collected separately from those formed afterwards. Green fruits, mature fruits, and roots were harvested separately as well. The various plant parts were dried at ${ }^{\circ} \mathrm{C} 70$ and weighed, and ${ }^{15} \mathrm{~N}$, total $\mathrm{N},{ }^{85} \mathrm{Rb}$, and $\mathrm{K}$ were determined.

Total $\mathrm{N}\left(\mathrm{N}_{\mathrm{t}}\right)$ was analyzed by the semi-micro Kjeldahl method as described by Malavolta et al. (1997). The isotopic determination of $\mathrm{N}$ contained in the samples was made by mass spectrometry, using a modified Dumas method according to Trivelin et al. (1973). The ${ }^{15} \mathrm{~N}$ analyses were made following there steps: a) conversion of the enriched nitrogen into ammonia; b) conversion of ammonia into $\mathrm{N}_{2}$; and c) determination of the isotopic dilution by mass spectrometry. The results of the $\mathrm{N}_{2}$ isotopic composition were obtained with mass members 28, 29, 30: $\mathrm{I}_{28}$ $\left({ }^{14} \mathrm{~N}^{14} \mathrm{~N}\right) ; \mathrm{I}_{29}\left({ }^{15} \mathrm{~N}^{14} \mathrm{~N}\right) ; \mathrm{I}_{30}\left({ }^{15} \mathrm{~N}^{15} \mathrm{~N}\right)$. From the intensity (I) of the peaks ( $\mathrm{I}=$ height in $\mathrm{mm}$ times sensitivity volts), the percent concentrations of ${ }^{15} \mathrm{~N}$ atoms was derived from the following equation: Atoms $\%{ }^{15} \mathrm{~N}=\left[\left(\mathrm{I}_{29}+\right.\right.$ $\left.\left.2 \times \mathrm{I}_{30}\right) /\left(2 \times \mathrm{I}_{28}+2 \times \mathrm{I}_{29}+2 \times \mathrm{I}_{30}\right)\right] \times 100$. This equation can also be written as: atoms $\%{ }^{15} \mathrm{~N}=\left[\left(\mathrm{n}\right.\right.$. atoms $\left.{ }^{15} \mathrm{~N}\right) /$ (n. atoms ${ }^{14} \mathrm{~N}+\mathrm{n}$. atoms $\left.\left.{ }^{15} \mathrm{~N}\right)\right] \times 100$. The extraction of both $\mathrm{K}$ and $\mathrm{Rb}$ from the plant material was made through nitric perchloric acid extraction. The $\mathrm{K}$ was determined by flame photometry and the $\mathrm{Rb}$ was assessed by atomic absorption (Malavolta et al., 1997).

The quantity of ${ }^{15} \mathrm{~N}$ accumulated in the mineral organs was calculated by the equation $\mathrm{C}=\left(\mathrm{A} \times \mathrm{N}_{\mathrm{t}}\right) /$ 100 , wherein $\mathrm{C}={ }^{15} \mathrm{~N}$ accumulated; $\mathrm{A}=$ atoms $\%{ }^{15} \mathrm{~N}$ in excess in the organ; $\mathrm{N}_{t}=$ total nitrogen accumulated in the organ. Nitrogen remobilized or exported $\left(\mathrm{N}_{\mathrm{R}}\right)$ from the organs of reserve was calculated by the equation: $\left.\mathrm{N}_{\mathrm{R}}=\left[\mathrm{C}_{1}-\mathrm{C}_{2}\right) / \mathrm{A}_{1}\right] \times 100$, wherein $\mathrm{C}_{1}=$ total ${ }^{15} \mathrm{~N}$ content in the organ of reserve immediately after the labelled period (initial harvest); $\mathrm{C}_{2}=$ total content of ${ }^{15} \mathrm{~N}$ in the organ of reserve at the moment of the final harvest (ripe berries); $\mathrm{A}_{1}=$ atoms of $\%$ of ${ }^{15} \mathrm{~N}$ in excess in the organ of reserve immediately after the labelling period (initial harvest).

The $\mathrm{N}$ percent re-utilized from the organs of reserve, in relation to total $\mathrm{N}$ accumulated in the organs formed before or after flower differentiation was estimated with the following expression: $\% \mathrm{U}=$ $\left[\left(\mathrm{N}_{\mathrm{t}} \times \mathrm{A}_{2}\right) / \mathrm{A}_{1}\right] \times 100$, wherein $\mathrm{N}_{\mathrm{t}}=$ total $\mathrm{N}$ in the organ under study; $A_{1}=$ atoms $\%$ of ${ }^{15} \mathrm{~N}$ in excess in the organ of reserve immediately after the labelling period (initial harvest); $\mathrm{A}_{2}=$ atoms $\%$ of ${ }^{15} \mathrm{~N}$ in excess in the organ under study.

The abundance of $\mathrm{Rb}$ in the labelled samples was calculated with the equation: $\mathrm{ab} . \mathrm{Rb}=[\mathrm{mol} \mathrm{Rb} /$ $(\mathrm{mol} \mathrm{Rb}+\mathrm{mol} \mathrm{K})] \times 100$. The excess abundance of $\mathrm{Rb}(\mathrm{ab} \cdot \mathrm{Rb} \mathrm{exc})$ was estimated by using the expression $a b \cdot R b_{\text {exc }}=a b \cdot R b-a b \cdot R b_{\text {nat }}$, wherein $a b$. $\mathrm{Rb}_{\text {nat }}=$ natural abundance of $\mathrm{Rb}$. The remaining calculations concerning $\mathrm{K}$ and $\mathrm{Rb}$ were similar to those described for nitrogen. 


\section{RESULTS AND DISCUSSION}

\section{Initial harvest}

Table 1 shows data from the first harvest, before flowering, when all plant parts were labelled by ${ }^{15} \mathrm{~N}$ and ${ }^{85} \mathrm{Rb}$ derived from the substrate. It can be seen that flower buds had a $\mathrm{N}$ level $30 \%$ higher than the leaves, whereas their K content was $31 \%$ lower. Nearly half of the plant $\mathrm{N}$ was in the leaves (45.9\%); roots came next (32.9\%). Branches and flower buds had $10.6 \%$ each. In the case of K, $53.1 \%$ was in the leaves, with $32.6 \%$ in the roots, whereas branches and flower buds had only $7.8 \%$ and $6.4 \%$, respectively.

The excess abundance of ${ }^{85} \mathrm{Rb}$ and the percent of excess ${ }^{15} \mathrm{~N}$ atoms in the several parts showed low coefficients of variation. There was high enrichment for both isotopes, made necessary due to the expected dilution caused by plant growth 10 months after labelling. Within this period plants with adequate $\mathrm{N}$ and $\mathrm{K}$ nutrition increased their dry matter fourfold.

\section{Final harvest}

Leaf analysis carried out at the final harvest in fruit-bearing branches of $\mathrm{N}$ or $\mathrm{K}$ deficient plants showed a $30 \%$ drop in $\mathrm{N}$ level, and one of $67 \%$ in $\mathrm{K}$ concentration in relation to the adequately supplied plants. Normal plants had $23 \mathrm{mg} \mathrm{kg}^{-1} \mathrm{~N}$ and $25 \mathrm{mg}$ $\mathrm{kg}^{-1} \mathrm{~K}$, whereas the deficient ones had $16 \mathrm{mg} \mathrm{kg}^{-1}$ and $6 \mathrm{mg} \mathrm{kg}^{-1}$, respectively. The more pronounced K-level drop was not accompanied by a proportional decrease in plant dry matter and fruit production. Average yield of the $\mathrm{N}$ and $\mathrm{K}$ deficient plants was similar. Meanwhile the vegetative biomass of the potassium deficient plants was higher than that of the $\mathrm{N}$ deficient ones (Table 2).

In all treatments the lowering of the $\mathrm{N}$ and $\mathrm{K}$ content in leaves produced either before or during the isotopic enrichment period, through the reproductive process was due to export into fruit and new organs during leaf senescence. Leaf fall also represented additional total $\mathrm{N}$ and $\mathrm{K}$ loss. Potassium and nitrogen are highly phloem mobile elements, and their re-utilization leads to rapid decline in their level in vegetative parts, thereby inducing earlier senescence (Marschner, 1995). Thus, nitrogen deficient plants grew less and produced fewer leaves, branches, and roots. Plants with adequate nutrition yielded, on the average, $56 \mathrm{~g}$ of dry fruits.

TABLE 1

Content of $\mathrm{N}, \mathrm{K}$, and $\mathrm{Rb}$, atoms $\%{ }^{15} \mathrm{~N}$ in excess, abundance in excess of ${ }^{85} \mathrm{Rb}$, dry matter, and quantity of $\mathrm{N}$ and $\mathrm{K}$ in organs of reserve of the coffee plants before flowering.

\begin{tabular}{|c|c|c|c|c|c|c|c|}
\hline Organ & & $\begin{array}{c}\mathrm{N} \\
\left(\mathrm{g} \mathrm{kg}^{-1}\right)\end{array}$ & $\begin{array}{c}\text { Atoms } \%{ }^{15} \mathrm{~N} \text { in } \\
\text { excess } \\
(\%)\end{array}$ & $\begin{array}{c}\mathrm{K} \\
\left(\mathrm{g} \mathrm{kg}^{-1}\right)\end{array}$ & $\begin{array}{c}{ }^{85} \mathrm{Rb} \\
\left(\mathrm{g} \mathrm{kg}^{-1}\right)\end{array}$ & $\begin{array}{c}\text { Abundance in } \\
\text { excess }{ }^{85} \mathrm{Rb} \\
(\%)\end{array}$ & $\begin{array}{c}\text { Dry matter } \\
\left(\text { g plant }^{-1}\right)\end{array}$ \\
\hline \multirow{2}{*}{ Leaves } & Average & 31 & 1.363 & 22 & 6.6 & 0.394 & 66.99 \\
\hline & C.V.\% & 14.2 & 7.5 & 6.1 & 9.7 & 8.2 & 16.4 \\
\hline \multirow{2}{*}{ Branches } & Average & 18 & 1.259 & 08 & 4.0 & 0.516 & 27.02 \\
\hline & C.V.\% & 7.4 & 6.8 & 21.2 & 17.0 & 4.7 & 16.6 \\
\hline \multirow{2}{*}{ Roots } & Average & 36 & 1.649 & 22 & 21.1 & 0.645 & 41.13 \\
\hline & C.V.\% & 24.4 & 11.6 & 14.4 & 46.7 & 11.3 & 13.6 \\
\hline \multirow{2}{*}{$\begin{array}{c}\text { Flower } \\
\text { buds }\end{array}$} & Average & 40 & 1.893 & 15 & 3.3 & 0.321 & 11.92 \\
\hline & C.V.\% & 5.3 & 5.2 & 12.5 & 11.6 & 16.3 & 3.4 \\
\hline \multirow{2}{*}{$\begin{array}{c}\text { Leaf } \\
\text { analysis }\end{array}$} & Average & 36 & - & 25 & - & - & 一 \\
\hline & C.V.\% & 26.6 & - & 4.7 & - & - & - \\
\hline
\end{tabular}


TABLE 2

Dry matter of the various parts of the coffee plant at final harvest.

\begin{tabular}{|c|c|c|c|c|c|c|c|c|c|c|}
\hline \multirow{3}{*}{$\begin{array}{c}\text { Nutritional } \\
\text { status }\end{array}$} & & \multicolumn{2}{|c|}{ Leaves } & \multicolumn{2}{|c|}{ Branches } & \multirow[b]{2}{*}{ Roots } & \multicolumn{3}{|c|}{ Fruits } & \multirow[b]{2}{*}{ Total } \\
\hline & & $\begin{array}{c}\text { Anterior } \\
\text { flush }\end{array}$ & $\begin{array}{c}\text { Posterior } \\
\text { flush }\end{array}$ & $\begin{array}{c}\text { Anterior } \\
\text { flush }\end{array}$ & $\begin{array}{c}\text { Posterior } \\
\text { flush }\end{array}$ & & Greens & Ripe & Total & \\
\hline & \multicolumn{10}{|c|}{ g plant ${ }^{-1}$} \\
\hline \multirow{2}{*}{ N e K-normal } & Average & $14.06 \mathrm{a}^{*}$ & $97.45 \mathrm{a}$ & $126.76 \mathrm{a}$ & $53.04 \mathrm{a}$ & $112.36 \mathrm{a}$ & $15.48 \mathrm{a}$ & $45.39 \mathrm{a}$ & $56.22 \mathrm{a}$ & $464.55 \mathrm{a}$ \\
\hline & C.V.\% & 102.5 & 22.2 & 11.9 & 27.9 & 18.3 & 190.7 & 97.9 & 85.0 & 12.0 \\
\hline \multirow{2}{*}{ N-deficient } & Average & $21.84 \mathrm{a}$ & $72.18 \mathrm{~b}$ & $98.76 \mathrm{~b}$ & $21.87 \mathrm{~b}$ & $83.79 \mathrm{~b}$ & $1.87 \mathrm{a}$ & $32.21 \mathrm{a}$ & $33.14 \mathrm{a}$ & $328.58 \mathrm{~b}$ \\
\hline & C.V.\% & 103.6 & 18.3 & 13.0 & 25.0 & 14.3 & 53.7 & 133.4 & 131.2 & 12.8 \\
\hline \multirow{2}{*}{ K-deficient } & Average & $11.35 \mathrm{a}$ & $94.85 \mathrm{a}$ & $121.44 \mathrm{a}$ & $48.30 \mathrm{a}$ & $116.80 \mathrm{a}$ & $1.90 \mathrm{a}$ & $27.67 \mathrm{a}$ & $2923 \mathrm{a}$ & $422.31 \mathrm{a}$ \\
\hline & C.V.\% & 49.3 & 15.6 & 12.0 & 19.6 & 17.6 & 89.6 & 151.1 & 143.0 & 7.4 \\
\hline
\end{tabular}

* Values followed by different letters on the vertical are statistically different (Tukey) at $1 \%$ level.

The Potassium deficient plants produced nearly $50 \%$ less and those deficient in nitrogen produced $40 \%$ below normal. There was, however, a marked lack of uniformity in fruit formation which caused a high coefficient of variation insofar as yield is concerned. For this reason the statistical analysis failed to show significant differences among treatments. The statistical test does not take into consideration the fact that $80 \%$ of the coffee plants adequately fed with both $\mathrm{N}$ and $\mathrm{K}$ yielded more than $10 \mathrm{~g}$ dry fruits, and $60 \%$ of such plants had a production higher than 50 grams. On the other hand, the $\mathrm{N}$ and $\mathrm{K}$ deficient treatments showed yields lower than $10 \mathrm{~g}$ in 46 and $58 \%$ of the parcels, respectively. Yields higher than $50 \mathrm{~g}$ were registered only in $18 \%$ and $17 \%$ of the $\mathrm{N}$ and $\mathrm{K}$ deficient plants, respectively.

\section{Nutritional status at final harvest}

Table III shows the concentrations of N, K, and $\mathrm{Rb}$ in the several organs as a function of the treatments. Nitrogen deficient plants suffered a $24 \%$ reduction of that element in leaves of the later flushing and in branches of both flushes. Leaves from the early flush had a $34 \%$ reduction in $\mathrm{N}$ level. The drop in fruit $\mathrm{N}$ averaged circa $45 \%$. Root $\mathrm{N}$ was not affected by the limitation in $\mathrm{N}$ supply in the substrate. This is probably due to the fact that the main source of nutrients for phloem loading are branches and leaves, from which remobilization takes place, with reproductive and growing vegetative organs acting as drains. In the case of $\mathrm{K}$ deficient plants, leaves from the early flush and root as well showed an almost $40 \%$ drop in the content of that element. Leaves and branches of the later flush showed a $45 \%$ and $30 \%$ drop, respectively. The lowest reduction in $\mathrm{K}$ concentration, around $16 \%$, took place in the branches of the early flush.

From Tables 2 and 3 the relationship between the quantities of $\mathrm{N}$ and $\mathrm{K}$ accumulated at the end of fruit ripening in the normal plants is derived. The $\mathrm{K} / \mathrm{N}$ ratio was variable according to the organ considered and the period of its formation, i.e., before or after differentiation of flower buds: leaves from the early flush -0.5 , leaves from the later flush 0.8 ; branches from the early flush -0.7 , branches from the later flush -1.4 ; roots -0.9 , fruits -1.1 ; general average -1.0 . Before flowering the ratios were: 0.7 for leaves, 0.5 for branches, 0.6 for roots, and 0.4 for flowering buds; general average 0.6 . This means that the $\mathrm{N}$ buildup in relation to $\mathrm{K}$ tends to decrease in the whole plant during the period of fruit growth. This finding is well defined in the branches of the later flush and in the roots. Before flowering, the total $\mathrm{N}$ content was $60 \%$ higher than that of $\mathrm{K}$, whereas during the fruit ripening stage, the content of both nutrients was similar in the fruits and in the total as well.

Taking into account the existing reserves in the flower buds, there was an average $133 \%$ increase in the reproductive apparatus $\mathrm{N}$ content of the normal plants, against an almost $30 \%$ decrease in the deficient ones. 
TABLE 3

Total content of $\mathrm{N}, \mathrm{K}$, and $\mathrm{Rb}\left(\mathrm{mg} \mathrm{kg}^{-1}\right)$ in organs of the flushes before and after labelling with ${ }^{15} \mathrm{~N}$ and ${ }^{85} \mathrm{Rb}$.

\begin{tabular}{|c|c|c|c|c|c|c|c|c|}
\hline \multirow{3}{*}{$\begin{array}{l}\text { Nutritional } \\
\text { status }\end{array}$} & & \multicolumn{2}{|c|}{ Leaves } & \multicolumn{2}{|c|}{ Branches } & \multirow[b]{2}{*}{ Roots } & \multicolumn{2}{|c|}{ Fruits } \\
\hline & & $\begin{array}{c}\text { Anterior } \\
\text { flush }\end{array}$ & $\begin{array}{c}\begin{array}{c}\text { Posterior } \\
\text { flush }\end{array} \\
\end{array}$ & $\begin{array}{c}\text { Anterior } \\
\text { flush }\end{array}$ & $\begin{array}{c}\begin{array}{c}\text { Posterior } \\
\text { flush }\end{array} \\
\end{array}$ & & $\begin{array}{c}\text { Green } \\
\text { (enlargement) }\end{array}$ & $\begin{array}{c}\text { Ripe } \\
\text { (berry) }\end{array}$ \\
\hline & \multicolumn{8}{|c|}{ Nitrogen } \\
\hline \multirow{2}{*}{ N-normal } & Average & 25.6 & 20.5 & 7.6 & 9.7 & 22.0 & 22.3 & 18.9 \\
\hline & C.V.\% & 16.9 & 12.7 & 3.5 & 11.5 & 16.1 & 15.4 & 13.9 \\
\hline \multirow{3}{*}{ N-deficient } & Average & 16.9 & 15.6 & 5.8 & 7.4 & 21.7 & 12.0 & 11.0 \\
\hline & C.V.\% & 6.9 & 5.6 & 11.0 & 6.1 & 7.3 & 3.9 & 8.7 \\
\hline & \multicolumn{8}{|c|}{ Potassium } \\
\hline \multirow{2}{*}{ K-normal } & Average & 11.8 & 15.7 & 5.7 & 133 & 21.0 & 21.3 & 20.5 \\
\hline & C.V.\% & 37.2 & 15.2 & 22.8 & 17.3 & 23.5 & 5.7 & 3.7 \\
\hline \multirow{3}{*}{ K-deficient } & Average & 7.2 & 8.6 & 4.8 & 7.4 & 1.31 & 14.8 & 14.5 \\
\hline & C.V.\% & 19.2 & 15.0 & 11.0 & 15.4 & 18.8 & 11.2 & 7.0 \\
\hline & \multicolumn{8}{|c|}{ Rubidium } \\
\hline \multirow{2}{*}{ K-normal } & Average & 1.6 & 1.3 & 0.7 & 1.0 & 2.2 & 2.7 & 2.5 \\
\hline & C.V.\% & 38.0 & 22.2 & 26.5 & 18.2 & 29.6 & 15.1 & 12.5 \\
\hline \multirow{2}{*}{ K-deficient } & Average & 1.5 & 1.6 & 0.9 & 1.9 & 3.2 & 3.9 & 3.7 \\
\hline & C.V.\% & 22.1 & 21.8 & 17.7 & 19.0 & 18.7 & 15.7 & 16.8 \\
\hline
\end{tabular}

On the other hand, there a was a 530\% increase in $\mathrm{K}$ content of the fruits of the well-supplied plants, and one of $127 \%$ in those from $\mathrm{K}$ deficient plants. The $\mathrm{N}$ quantity decrease which took place in the deficient plant reproductive organs between the stages of flowering buds and berry is due, in part, to the presence of few of the first, which had failed to develop, and mainly to the severe reduction in fruit $\mathrm{N}$ in relation to that of flower buds, which was 3.6 times lower, accompanied by a dry matter increase of only $180 \%$.

\section{Remobilization and re-utilization of nitrogen and potassium}

The main reserve of $\mathrm{N}\left(\mathrm{N}_{\mathrm{R}}\right)$ which was used by the organs formed after flower bud initiation was the photosynthetic apparatus. Storage and remobilization or export of $N_{R}$ from the leaves contributed greatly to the growth of new organs and the reproductive organs. The period between anthesis and final expansion of fruits strongly drains minerals and photoassilates. In the coffee plant nitrate reduction activity increases considerably in the final stage of flower development, in the beginning of endosperm formation, and during the final phase of bean enlargement. During these physiological stages anabolism increases within the leaves, thereby meeting the demand for metabolites (Carelli et al., 1989).

Leaves accounted for more than $50 \%$ of total $\mathrm{N}_{\mathrm{R}}$ exported both in normal (47\%-58\%) and $\mathrm{N}$ deficient plants (49\%-65\%). Branches (orthotropic and plagiotropic) and buds exported from $20 \%$ to $21 \%$ in normal plants, and $21 \%$ to $27 \%$ in the deficient ones. Roots contributed with $21 \%$ to $32 \%$ in plants with adequate $\mathrm{N}$ supply, and $14 \%$ to $25 \%$ in the deficient plants. In citrus plants Legaz et al. (1995) found $40 \%-50 \%$ for leaves, $15 \%-25 \%$ for branches, and $30 \%-35 \%$ for the roots. The $\mathrm{N}_{\mathrm{R}}$ contribution from each organ was, therefore, similar (Table 4). 
TABLE 4

Export of $\mathbf{N}$ by organs formed before flower differentiation and contribution of reserve $\mathrm{N}$ to total $\mathrm{N}$ accumulation at harvest.

\begin{tabular}{|c|c|c|c|c|c|c|c|}
\hline \multicolumn{8}{|c|}{ Nitrogen exported by organs of reserve (as \% of total K) } \\
\hline \multicolumn{4}{|c|}{ Normal plants } & \multicolumn{4}{|c|}{ Deficient plants } \\
\hline Leaves & \multicolumn{2}{|c|}{ Branches + Buds } & Roots & Leaves & \multicolumn{2}{|c|}{ Branches + Buds } & Roots \\
\hline $52.5(9.7)^{*}$ & \multicolumn{2}{|c|}{$20.7(3.9)$} & $26.8(20.8)$ & $56.9(13.0)$ & \multicolumn{2}{|c|}{$24.0(13.5)$} & $19.2(28.2)$ \\
\hline \multicolumn{8}{|c|}{ Utilization (\%) of $\mathrm{N}$ from organs of reserve by organs formed before and after differentiation of flower buds } \\
\hline \multicolumn{4}{|c|}{ Normal plants } & \multicolumn{4}{|c|}{ Deficient plants } \\
\hline \multicolumn{2}{|c|}{ Anterior flush } & \multicolumn{2}{|c|}{ Posterior flush } & Anterior & ush & \multicolumn{2}{|c|}{ Posterior flush } \\
\hline \multicolumn{4}{|c|}{ Leaves } & \multicolumn{4}{|c|}{ Leaves } \\
\hline \multicolumn{2}{|c|}{$57.9(10.0)$} & \multicolumn{2}{|c|}{$17.5(10.7)$} & \multicolumn{2}{|c|}{$80.8(9.5)$} & \multicolumn{2}{|c|}{$50.0(3.8)$} \\
\hline \multicolumn{4}{|c|}{ Branches } & \multicolumn{4}{|c|}{ Branches } \\
\hline \multicolumn{2}{|c|}{31.1 (4.6) } & \multicolumn{2}{|c|}{$19.8(3.8)$} & 53.9 & & \multicolumn{2}{|c|}{$49.5(7.0)$} \\
\hline \multicolumn{4}{|c|}{ Roots } & \multicolumn{4}{|c|}{ Roots } \\
\hline \multicolumn{4}{|c|}{$24.3(14.5)$} & \multicolumn{4}{|c|}{$56.3(4.8)$} \\
\hline \multicolumn{4}{|c|}{ Fruits } & \multicolumn{4}{|c|}{ Fruits } \\
\hline \multicolumn{4}{|c|}{$22.7(9.1)$} & \multicolumn{4}{|c|}{$46.0(5.5)$} \\
\hline
\end{tabular}

* Figures between parenthesis correspond to the coefficient of variation $(\%)$.

Nutritional status influences both distribution of freshly absorbed elements and remobilização of previously acquired ones. These processes, therefore, play a fundamental role in the relationship between nutrient content and growth (Smith, 1986). The utilization of $\mathrm{N}$ derived from the reserve organs by those formed after flower initiation and differentiation in the deficient plants was markedly higher than in those well supplied with that element. In the organs of reserve of $\mathrm{N}$ deficient plants a higher proportion of the element was taken up before the differentiation of flower primordia. This suggests that in the deficient plants $\mathrm{N}$ absorbed from the nutrient solution was preferentially transported to growing organs in a proportion much higher than that found in the well nourished plants.

During fruit ripening $\mathrm{N}_{\mathrm{R}}$ is found mainly in the roots besides leaves from the later flush and fruits. The $\mathrm{N}_{\mathrm{R}}$ quantity in the fruits is a function of the load, reaching up to $25 \%$ of the total $N_{R}$ in the case of wellfed plants. In the deficient plants the value is lower by nearly $15 \%$. The reproductive organs represent an important drain: root activity and nutrient uptake decrease because less carbohydrates are supplied, being preferentially directed to the fruits.
Immediately after ${ }^{85} \mathrm{Rb}$ was withdrawn from the nutrient solution (first harvest), no correlation $(\mathrm{r}=-0.41 \mathrm{~ns})$ between concentrations of $\mathrm{K}$ and the isotope in the leaves was observed. In branches and roots, however, the correlation was high and significant ( $\mathrm{r}=0.90^{* *}$ for both organs). In the final harvest, regression analyses in various organs formed before or after the omission of ${ }^{85} \mathrm{Rb}$ from the substrate presented high correlation between the contents of re-utilized ${ }^{85} \mathrm{Rb}$ e K. It should be kept in mind that, for the organs of the late flush, these correlations involve both endogenous and exogenous $\mathrm{K}$, whereas $\mathrm{Rb}$ is exclusively endogenous (Fig. 1).

The export of reserve $\mathrm{K}\left(\mathrm{K}_{\mathrm{R}}\right)$ occurred mainly from the leaves, and to a lesser extent, from the roots, as was the case with $\mathrm{N}$. Branches and buds exported very little $\mathrm{K} . \mathrm{K}_{\mathrm{R}}$ contributed $54 \%$ to $63.8 \%$ of the total exported in normal plants, and $61.8 \%$ to $79.2 \%$ in the deficient ones.

Roots from adequately supplied plants contributed $30.2 \%$ to $41.0 \%$ whereas those from deficient plants contributed $20 \%$ to $33.4 \%$ of the total. It follows that deficient plants tend to re-utilize preferentially leaf $\mathrm{K}$ (Table 5). 


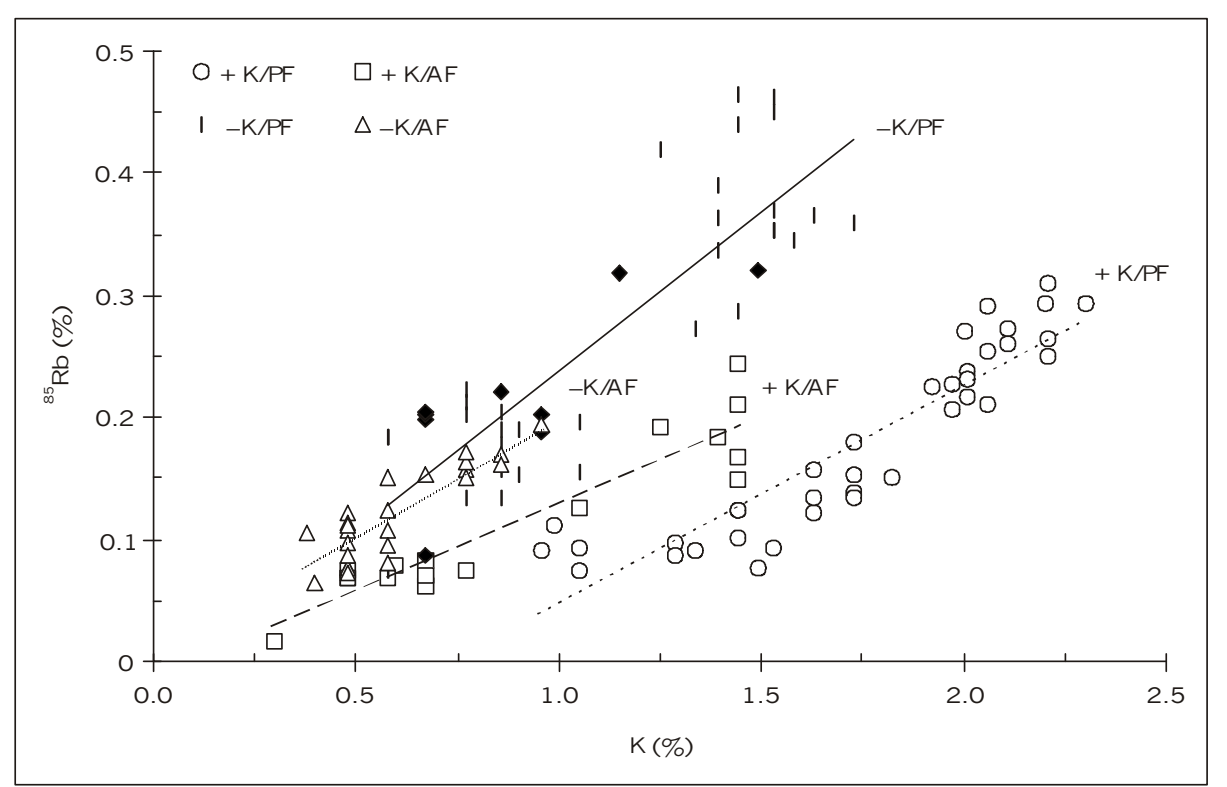

Fig. 1 - Correlation between $\mathrm{K}$ and ${ }^{85} \mathrm{Rb}$ taken up by roots of normal or deficient coffee plants, and transported into leaves and branches before flowering (early flush), and between $\mathrm{K}$ and ${ }^{85} \mathrm{Rb}$ re-utilized from reserve organs into leaves, branches, and fruits produced after labelling with ${ }^{85} \mathrm{Rb}$ (late flush).

$+\mathrm{K} / \mathrm{FP}=$ leaves, branches, and fruits of plants with sufficient $\mathrm{K}-$ flush after labelling with ${ }^{85} \mathrm{Rb} ;+\mathrm{K} / \mathrm{FA}$ leaves and branches of plants with sufficient $\mathrm{K}$ - flush before labelling with ${ }^{85} \mathrm{Rb}$; $-\mathrm{K} / \mathrm{FP}=$ leaves, branches, and fruits of plants of deficient $\mathrm{K}-$ flush after labelling with ${ }^{85} \mathrm{Rb}$; $-\mathrm{K} / \mathrm{FA}=$ leaves and branches of plants of deficient $\mathrm{K}-$ flush after labelling with ${ }^{85} \mathrm{Rb} .+\mathrm{K} / \mathrm{FP}: \mathrm{Rb}=$ $0,1801 \mathrm{~K}-0,1338 \mathrm{r}=0,91^{* *} ;+\mathrm{K} / \mathrm{FA}: \mathrm{Rb}=0,1451 \mathrm{~K}-0,1338 \mathrm{r}=0,94^{* *} ;-\mathrm{K} / \mathrm{FP}: \mathrm{Rb}=0,261 \mathrm{~K}-0,0233 \mathrm{r}=0,86^{* *} ;-\mathrm{K} / \mathrm{FA}:$ $\mathrm{Rb}=0,2004 \mathrm{~K}-0,0155 \mathrm{r}=0,87 * * *=$ significant at $5 \%$ level and $* *=$ significant at $1 \%$ level.

TABLE 5

Export of $K$ by organs formed before flower differentiation and contribution of reserve $K$ to the accumulation of total $K$ at harvest.

\begin{tabular}{|c|c|c|c|c|c|c|c|}
\hline \multicolumn{8}{|c|}{ Potassium exported by organs of reserve (as \% of total $\mathrm{K}$ ) } \\
\hline \multicolumn{4}{|c|}{ Normal plants } & \multicolumn{4}{|c|}{ Deficient plants } \\
\hline Leaves & \multicolumn{2}{|c|}{ Branches + Buds } & Roots & Leaves & \multicolumn{2}{|c|}{ Branches + Buds } & Roots \\
\hline $58.9(8.3)$ & \multicolumn{2}{|c|}{$5.5(54.0)$} & $35.6(15.1)$ & $70.5(12.3)$ & \multicolumn{2}{|c|}{$2.8(58.9)$} & $26.7(25.1)$ \\
\hline \multicolumn{8}{|c|}{ Utilization (\%) of K from organs of reserve by organs formed before and after differentiation of flower buds } \\
\hline \multicolumn{4}{|c|}{ Normal plants } & \multicolumn{4}{|c|}{ Deficient plants } \\
\hline Anterior & ush & \multicolumn{2}{|c|}{ Posterior Flush } & Anterio & lush & \multicolumn{2}{|c|}{ Posterior Flush } \\
\hline \multicolumn{4}{|c|}{ Leaves } & \multicolumn{4}{|c|}{ Leaves } \\
\hline $47.0(1$ & & \multicolumn{2}{|c|}{$32.3(16.4)$} & 65.1( & & \multicolumn{2}{|c|}{$60.5(13.0)$} \\
\hline \multicolumn{4}{|c|}{ Branches } & \multicolumn{4}{|c|}{ Branches } \\
\hline \multicolumn{2}{|c|}{$41.4(20.8)$} & \multicolumn{2}{|c|}{$29.6(12.0)$} & 60.4( & & \multicolumn{2}{|c|}{$74.0(16.3)$} \\
\hline \multicolumn{4}{|c|}{ Roots } & \multicolumn{4}{|c|}{ Roots } \\
\hline \multicolumn{4}{|c|}{$38.6(15.2)$} & \multicolumn{4}{|c|}{$72.6(8.3)$} \\
\hline \multicolumn{4}{|c|}{ Fruits } & \multicolumn{4}{|c|}{ Fruits } \\
\hline \multicolumn{4}{|c|}{$42.9(6.7)$} & \multicolumn{4}{|c|}{$73.6(10.7)$} \\
\hline
\end{tabular}

* Numbers between parenthesis correspond to the coefficient of variation (\%). 
The average $\mathrm{K}_{\mathrm{R}}$ quantity in the plant at harvest time was equivalent to $36 \%$ of the total in the wellfed plants, against $67 \%$ in the deficient ones. In the first, $\mathrm{K}_{\mathrm{R}}$ in the fruits reached $14 \%$ of the total, and in the latter it reached $34 \%$. These figures increase markedly when one considers the $\mathrm{K}_{\mathrm{R}}$ proportion in the fruit in relation to $\mathrm{K}_{\mathrm{R}}$ in the whole plant. In the plants without nutritional stress around $38 \%$ of the total $\mathrm{K}_{\mathrm{R}}$ was moved into the fruit. The corresponding value for the $\mathrm{K}$ deficient plants was $58 \%$. These values are higher than those corresponding to the $\mathrm{N}$ balance.

Three-year-old plants show that $20.6 \%$ to $24.8 \%$ of the fruit demand is met by reserves which exist when flower buds begin to develop. These values, however, increased twofold ( $43.5 \%$ to $48.5 \%$ ) when leaf $\mathrm{N}$ decreased by $30 \%$. On the other hand, $40 \%$ to $45.7 \%$ of fruit $\mathrm{K}$ is covered by potassium reserves at the same period. This contribution reached $65.7 \%$ to $81.4 \%$ when leaf $\mathrm{K}$ decreased $67 \%$. $\mathrm{K}_{\mathrm{R}}$ is used more intensively than $\mathrm{N}_{\mathrm{R}}$ by fruits and other organs of the coffee plant. These results point out the importance of $\mathrm{N}$ and $\mathrm{K}$ stored prior to flowering and exported and re-utilized during the reproductive cycle. The mathematical models which better demonstrate the relationship between utilization of $\mathrm{N}$ and $\mathrm{K}$ reserves and their leaf levels show it evens out in well-fed plants (Fig. 2).
Acknowledgments - This work was supported by FAPESP (State Foundation for Support of Research, State of São Paulo, Brazil), grant 96/01857-5, and by the Brazilian Research Council (CNPq), grant 300934/95-5.

\section{REFERENCES}

CALVACHE, M., PINO, I. \& BUNEDER, M., 1990, Posibilidades de uso de Rb-85 como trazador de potasio. Nucleotecnica, Santiago, 10(18): 43-45.

CALVACHE, M., ESPINOSA, J., CÓRDOVA, J. \& GANGOTENA, D., 1991, Determinación del potasio disponible en diferentes fuentes no marcadas (comerciales), utilizando Rb-85 como trazador. Nucleociencias, Quito, 2(2): 5-11.

CARELLI, M. L. C., FAHL, J. I. \& MAGALHÃES, A. C., 1989, Assimilação de nitrato durante o desenvolvimento reprodutivo de plantas de café. R. Bras. Ci. Solo, 13: 59-64.

CATANI, R. A. \& MORAES, F. R. P. de, 1958, A composição química do cafeeiro. Rev. Agr., Piracicaba, 33(1): 45-52.

CATANi, R. A., PEllegrino, D., AlCARDE, J. C. \& GRANER, C. A. F., 1967, Variação na concentração e na quantidade de macro e micronutrientes no fruto do cafeeiro durante o seu desenvolvimento. Anais da ESALQ, Piracicaba, 24: $249-263$.

CORREA, J. B., GARCIA, A. W. R. \& COSTA, P. C. da, 1983, Extração de nutrientes pelos cafeeiros Mundo Novo e Catuaí. In: Congresso Brasileiro de Pesquisas Cafeeiras, 10, Poços de Caldas, 1983. Anais... Rio de Janeiro, IBC/GERCA, pp. 177-183.

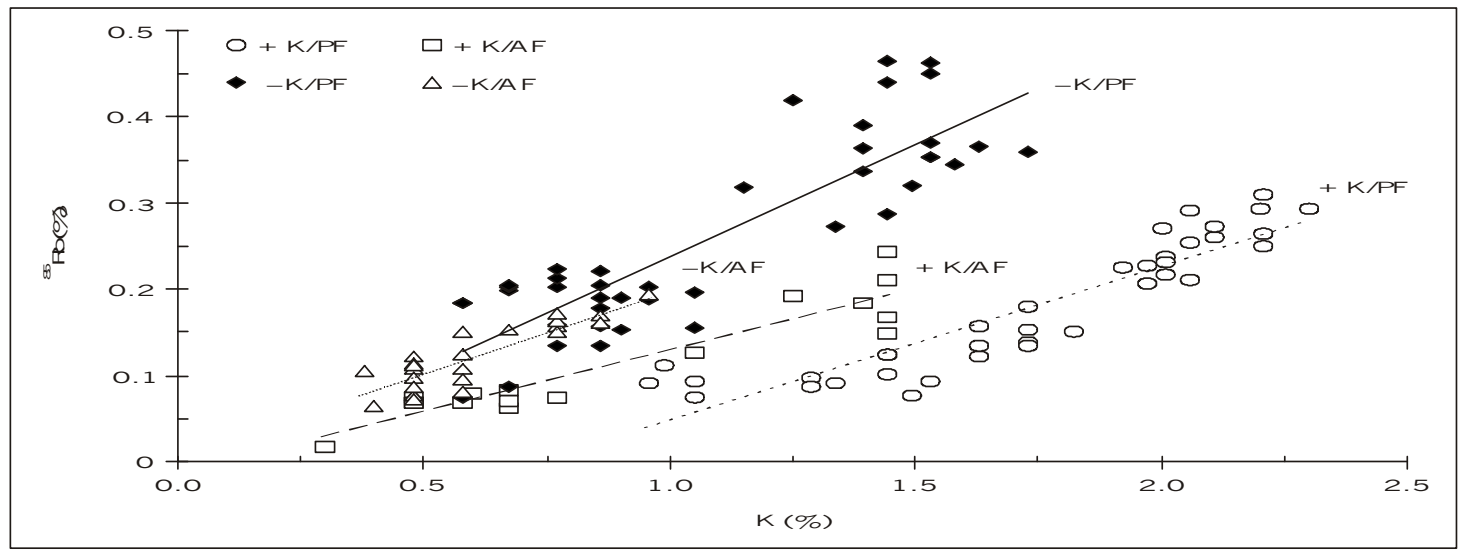

Fig. 2 - Utilization of $\mathrm{N}(\%$ UNDOR) and $\mathrm{K}(\%$ UKDOR), derived from organs of reserve by fruits, as a function of leaf $\mathrm{N}$ and $\mathrm{K}$. 
DIERENDONCK, F. J. E., 1959, The manuring of coffee, cocoa, tea and tobacco. Centro d'Étude de l'Ázote, Genebra.

ERDEI, L. \& TRIVEDI, S., 1991, Caesium/potassium selectivity in wheat and lettuce of different $\mathrm{K}^{+}$status. J. Plant Physiol., 138: 696-699.

GLANDER, H., 1958, Conocimientos y experiencias obtenidas en la abonadura del café. Verlagsgesellschaft für Ackerbau MBH (Bol. Verde n.8).

GUSSARSSON, M. \& JENSEN, P., 1992, Effects of copper and cadmium on uptake and leakage of $\mathrm{K}+$ in birch (Betula pendula) roots. Tree Physiol., 11: 305-313.

HUGHES, D. F., JOLLEY, V. D. \& BROWN, J. C., 1990, Differential response of dicotyledonous plants to potassiumdeficiency stress: iron-stress response mechanism. J. Plant Nutr., 13(11): 1405-1417.

KUHLMANN, H., 1990, Importance of the subsoil for the K nutrition of crops. Plant Soil, 127(1): 129-136.

LEGAZ, F., SERNA, M. D. \& PRIMO-MILLO, E., 1995, Mobilization of the reserve N in citrus. Plant Soil, 173: 205-210.

MARSCHNER, H., 1995, Mineral nutrition of higher plants. Academic Press Inc., New York, 887p.

MALAVOLTA, E., 1986, Nutrição, adubação e calagem para o cafeeiro. In: A. B. Rena, E. Malavolta, M. Rocha \& T. Yamada (eds.), Cultura do cafeeiro: fatores que afetam a produtividade. Potafós, Piracicaba, pp. 165-274.

MALAVOLTA, E., GRANER, E. A., SARRUGE, J. R. \& GOMES, L., 1963, Estudos sobre a alimentação mineral do cafeeiro. XI. Extração de macro e micronutrientes na colheita pelas variedades "Bourbon Amarelo", "Caturra Amarelo" e "Mundo Novo". Turrialba, 13(3): 188-189.
MALAVOLTA, E., VITTI, G. C. \& OLIVEIRA, S. A. de, 1997, Avaliação do estado nutricional das plantas: princípios e aplicações. 2. ed. Potafós, Piracicaba, 319p.

MITCHELL, H. W., 1988, Cultivation and harvesting of the arabica coffee tree. In: R. J. Clarke \& R. Macrae (eds.), Coffee: volume 4: agronomy. Elsevier Applied Science, London, 2: 43-90.

NAKAOJI, K., HARADA, H., WAKIUCHI, N., SUEYOSHI, K., OJI, Y. \& SHIGA, H., 1991, Proton-translocating inorganic pyrophosphatase in tonoplast vesicles from barley roots. Jap. J. Soil Sci. Plant Nutr., 62(4): 393-398.

PENG, J. G., LUO, T. \& CAI, A. Y., 1990, Tracer study on absorption and utilization rate of $\mathrm{K}$ fertilizers by rice plants. Fujian Agr. Sci. Tech., 4: 17-19.

PETTERSSON, S. \& STRID, H., 1989, Effects of aluminium on growth and kinetics of $\mathrm{K}^{+}\left({ }^{86} \mathrm{Rb}\right)$ uptake in two cultivars of wheat (Triticum aestivum) with different sensitivity to aluminium. Physiol. Plant., 76(3): 255-261.

SMITH, F. W., 1986, Interpretation of plant analysis: concepts and principles. In: D. J. Reuter \& J. B. Robinson (eds.), Plant analysis: an intepretation manual. Inkata, Melbourne, 19: $1-12$.

TRIVELIN, P. C. O., SALATI, E. \& MATSUI, E., 1973, Preparo de amostras para análise de ${ }^{15} \mathrm{~N}$ por espectrometria de massa. CENA, Piracicaba, 41p. (Boletim Técnico, n.2).

VOSE, P. B., 1980, Introduction to nuclear techniques in agronomy and plant biology. Pergamon Press, New York, $391 \mathrm{p}$. 